\title{
Variables related to nitrogen deposition improve defoliation models for European forests
}

\author{
Marco Ferretti • Marco Calderisi • Aldo Marchetto • Peter Waldner • \\ Anne Thimonier • Mathiew Jonard • Nathalie Cools • Pasi Rautio • \\ Nicholas Clarke • Karin Hansen • Päivi Merilä • Nenad Potočić
}

Received: 30 June 2014 / Accepted: 4 December 2014 /Published online: 30 December 2014

(C) INRA and Springer-Verlag France 2014

\begin{abstract}
- Key message Atmospheric deposition of nitrogen compounds and soil and foliar variables related to $\mathrm{N}$ deposition resulted important factors accounting for the variability of defoliation in European forest plots.

- Context Nitrogen $(\mathrm{N})$ deposition has increased in the northern hemisphere because of anthropogenic-related emission of $\mathrm{N}$ compounds. Increased $\mathrm{N}$ availability may have an adverse impact on forest sustainability.
\end{abstract}

\section{Handling Editor: Andrew Merchant}

Contribution of the co-authors Marco Ferretti: co-designing and supervising the work, and co-writing the paper.

Marco Calderisi: designing the statistical analyses.

Peter Waldner: co-designing the work, compiling the data set in collaboration with national experts and revising the paper.

Aldo Marchetto: co-designing the work, performing the quality control, running the statistical analyses and co-writing the paper.

Anne Thimonier, Matthiew Jonard, Nathalie Cools, Pasi Rautio, Nicholas Clarke, Karin Hansen, Päivi Merilä and Nenad Potočić: contributing important parts of the discussion of the results.

\section{Ferretti $\cdot$ M. Calderisi}

TerraData environmetrics, Via L. Bardelloni 19,

58025 Monterotondo Marittimo, GR, Italy

\section{A. Marchetto $(\square)$}

CNR-Istituto per lo Studio degli Ecosistemi, Largo Tonolli 50, 28922 Verbania Pallanza, VB, Italy

e-mail: a.marchetto@ise.cnr.it

P. Waldner $\cdot$ A. Thimonier

WSL, Swiss Federal Institute for Forest, Snow and Landscape

Research, Zürcherstrasse 111, 8903 Birmensdorf, Switzerland

\section{Jonard}

Université Catholique de Louvain, Earth and Life Institute, Croix du Sud, 2-L7.05.09, 1348 Louvain-la-Neuve, Belgium

N. Cools

INBO, Gaverstraat 4, 9500 Geraardsbergen, Belgium
- Aims This study aims to test the importance of throughfall $\mathrm{N}$ $\left(\mathrm{N}_{\text {thr }}\right)$ deposition in explaining the variability of the frequency of trees with defoliation $>25 \%\left(F_{25}\right)$, an indicator of forest condition.

- Methods A pan-European data set (71 plots) with enhanced quality control was considered. The additive effect of

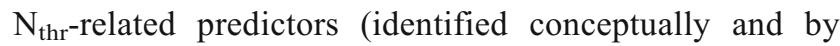
rank correlation) in explaining $F_{25}$ was investigated by partial least square regression in comparison with a reference model based on site, stand, management and climate data. Reported damage to foliage, $\mathrm{N}_{\text {thr }}$ deposition, foliar $\mathrm{N}$ ratios and mineral top-soil variables were added stepwise to the reference model.

- Results N-related variables improved defoliation models. Higher $\mathrm{N}_{\text {thr }}$ deposition led to higher $F_{25}$ for beech and Norway spruce, while the effect was opposite for Scots pine. Higher foliar $\mathrm{N}$ ratios led to higher $F_{25}$ for all species.

- Conclusion $\mathrm{N}_{\mathrm{thr}}$ deposition, damage to foliage, foliar $\mathrm{N} / \mathrm{P}$, $\mathrm{N} / \mathrm{Ca}, \mathrm{N} / \mathrm{Mg}, \mathrm{N} / \mathrm{K}$, top-soil $\mathrm{pH}, \mathrm{C} / \mathrm{N}$ and exchangeable base

\section{P. Rautio}

Finnish Forest Research Institute, Metla, Eteläranta 55,

96301 Rovaniemi, Finland

\section{N. Clarke}

Norwegian Forest and Landscape Institute, P.O. Box 115, 1431 Aas, Norway

\section{K. Hansen}

IVL Swedish Environmental Research Institute, Box 210 60, 100

31 Stockholm, Sweden

P. Merilä

Finnish Forest Research Institute, Metla, P.O. Box 413, 90014 Oulu, Finland

N. Potočić

Hrvatski Šumarski Institut, Cvjetno naselje 41, 10450 Jastrebarsko, Croatia 
cation resulted important factors (although with possible diverse effect) in explaining the variability of $F_{25}$ among plots.

Keywords Nitrogen deposition · Defoliation · ICP Forests . Europe

\section{Introduction}

The human-induced alteration of the nitrogen $(\mathrm{N})$ cycle has caused a three to five times increase in atmospheric inorganic $\mathrm{N}$ deposition (largely nitrate and ammonium) during the last century, with a further increase by a factor of 2.5 projected at a global level by the end of this century (Lamarque et al. 2005). $\mathrm{N}$ availability controls the productivity of many forest ecosystems, and, under $\mathrm{N}$ limitation, increased $\mathrm{N}$ deposition stimulates growth and enhances carbon (C) sequestration. On the other hand, when $\mathrm{N}$ is not a limiting factor, further $\mathrm{N}$ addition by deposition may not stimulate growth because other nutrients become limiting (e.g. Erisman et al. 2011). In both cases, however, detrimental effects of increased $\mathrm{N}$ deposition on tree health have been reported due to nutrient imbalance, increased sensitivity to pests/pathogens (e.g. Roelofs et al. 1985), storms (e.g. Braun et al. 2003) and extreme weather conditions (e.g. Dobbertin 2005).

The response of forest ecosystems to $\mathrm{N}$ deposition can be evaluated by controlled experiments with $\mathrm{N}$ addition or by observational studies, e.g. long-term, large-scale monitoring. The experimental approach permits the identification of the effect of $\mathrm{N}$ inputs independently of other factors. Such an approach, however, is quite expensive and impractical with mature forests for which it has been generally restricted to a few sites or a limited period of time. Further, $\mathrm{N}$ treatments may not reflect the effect of chronic $\mathrm{N}$ deposition in terms of frequency and amount of $\mathrm{N}$ added. The analysis of observational data from long-term, large-scale concurrent monitoring of $\mathrm{N}$ deposition, tree nutrition, health and growth as well as important covariates such as soil and meteorological variables can be an alternative and complementary way of investigating the effects of $\mathrm{N}$ deposition on forests (Ferretti et al. 2014a). The potential for causal inference is lower in comparison with manipulative experiments, but observational approaches have the advantage of maintaining a high degree of realism with regard to environmental conditions and $\mathrm{N}$ deposition regimes. In this respect, the data collected at the intensive monitoring plots of the International Cooperative Programme on Assessment and Monitoring of Air Pollution Effects on Forests (ICP Forests) are an important asset for two main reasons (Ferretti and Fischer 2013): Plots cover a wide range of ecological conditions (including a marked $\mathrm{N}$ deposition gradient), and - despite some inconsistencies that may always happen in large-scale programs - data are collected according to comparable methods (Ferretti and Fischer 2013). In these plots, monitoring of tree condition is based on the assessment of "defoliation", a popular (and incorrect) term adopted to mean the reduction of foliage density on trees as compared to a reference standard. Despite several criticisms (e.g. Innes et al. 1993), the frequency of trees with defoliation $>25 \%$ (hereafter referred to as $F_{25}$, Ferretti and Fischer 2013) is largely used to report forest condition data and adopted as a Sustainable Forest Management (SFM) indicator under Criterion 2, Forest Health and Vitality (Forest Europe 2011). A number of factors, including stand age, meteorology, pests, and diseases were reported to explain most of the variation in defoliation (e.g. de Vries et al. 2014). The objective of this paper is to test the null hypothesis $\left(H_{0}\right)$ of no effect of throughfall $\mathrm{N}$ deposition $\left(\mathrm{N}_{\text {thr }}\right)$ and related variables (soil and foliar nutrients) in defoliation models. To do this, we evaluated the possible, additive influence of $\mathrm{N}$-related predictors and damage to foliage in explaining the spatial variability of $F_{25}$ once other important drivers (i.e. geography, stand, local climate and management) are taken into account.

\section{Material and methods}

\subsection{Monitoring sites and quality assurance}

Data were collected at the ICP Forests intensive monitoring (level II) permanent plots. Each plot consists of about $2500 \mathrm{~m}^{2}$ in which several monitoring activities are carried out (Ferretti and Fischer 2013). To minimise the effect of random annual variations and anomalies, we concentrated on mean values over a defined time window and considered plots for which deposition, meteorological and defoliation data were available for all the 3 years 2007-2009 (see below).

A number of quality assurance and quality control (QA/ QC) procedures are routinely carried out in order to improve accuracy and comparability over time and space (Ferretti and Fischer 2013).

Additional QA/QC checks were performed for this study, and only plots for which data passed the QA/QC ring tests for total $\mathrm{N}$ in deposition carried out in 2005 and 2009 were considered.

From this reduced data set, we considered plots with three main tree species (MTS) for which at least 15 plots were retained, namely beech (Fagus sylvatica L., $n=20$ ), Norway spruce [Picea abies (L.) Karst., $n=33$ ] and Scots pine plots (Pinus sylvestris L., $n=18$ ). The number of trees evaluated ranged from 18 to 304 per plot and year. All in all, 71 plots were selected in nine countries covering a large latitudinal gradient across Europe (Fig. 1). 


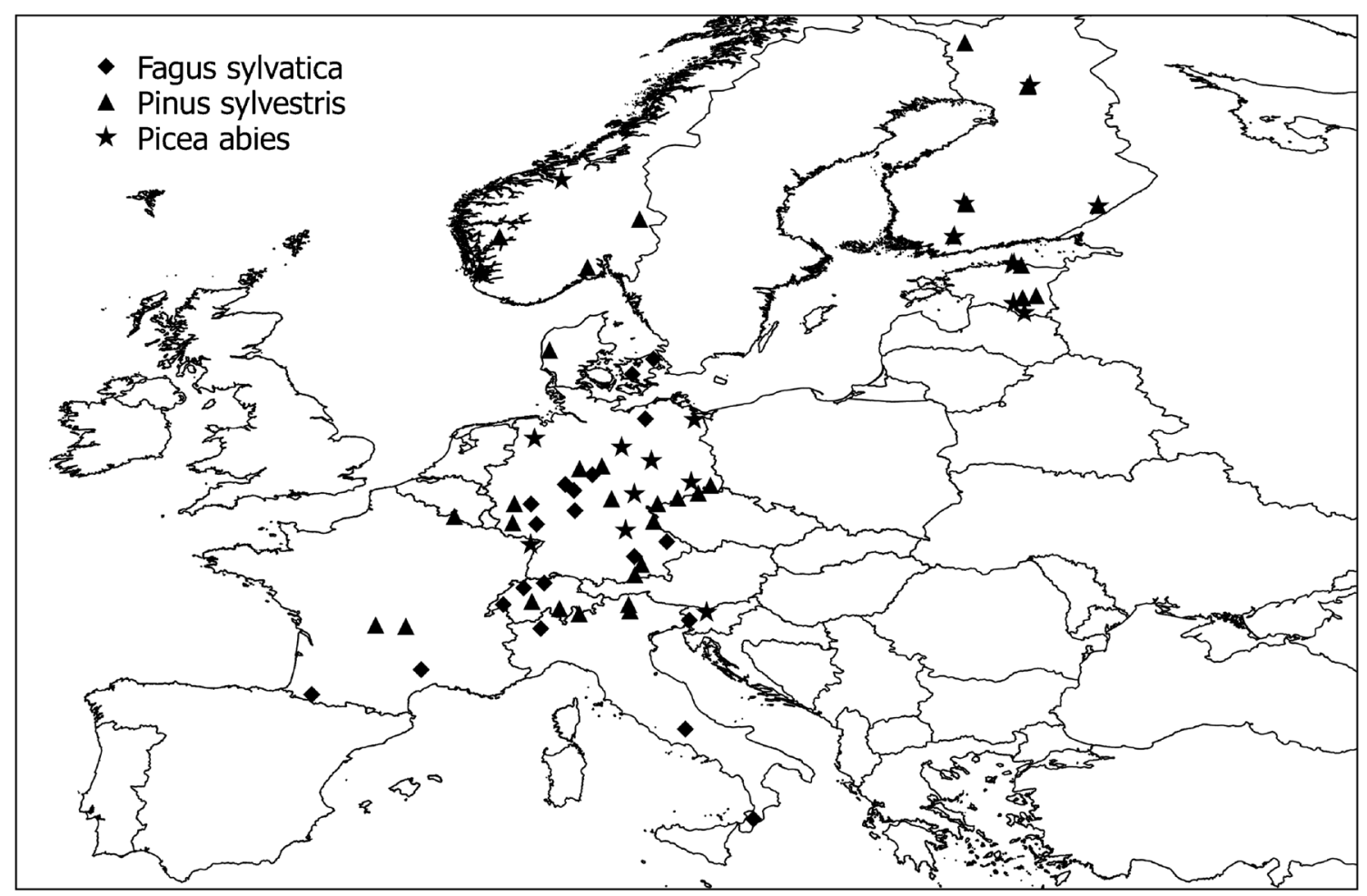

Fig. 1 Geographical distribution of the sampling plots

\subsection{Study concept}

The study concentrated on factors explaining the spatial variability of mean $F_{25}$ and was based on mean values per plot over a 3-year time window (2007-2009). Therefore, we did not consider time trends and were not concerned with time dependency. Within such a context, a stepwise procedure was adopted (Ferretti et al. 2014b): First, a reference model was considered, with geographical (latitude, longitude, elevation), stand (tree density) and meteorological variables (annual precipitation and per cent of precipitation occurring in summer) as predictors of $F_{25}$ (dependent variable). Secondly, individual sets of predictors were added stepwise to the reference model to evaluate their additional role in explaining $F_{25}$ (Table 1).

Since the number of plots with available data was not the same for all variables, we used three complete, internally consistent, aligned designs, each of them with a different number of plots, i.e. $n=71$ for testing the role of $\mathrm{N}_{\text {thr }}$ deposition and foliar damage; $n=65$ for testing the role of $\mathrm{N}$-foliar ratios; and $n=56$ for testing the role of soil variables. For each design, we compare the reference model (see above) against other models including additional variables. In this way, we were able to compare models based always on the same plots.

\subsection{Response and predictor variables}

The frequency of trees with defoliation higher than $25 \%\left(F_{25}\right)$ for the MTS in each plot was adopted as response variable.
Defoliation is the reduction of foliage density on a tree as compared to a reference standard, and it is visually assessed by trained observers according to semi-quantitative classes: $0 \%, 5 \%$ ( $>0-5 \%), 10 \%(>5-10 \%), \ldots, 99 \%(>95-100 \%$, when a tree is still alive) and $100 \%$ (dead tree) at $5 \%$ steps (see details in Ferretti and Fischer 2013). As any other ecological data based on visual observation, defoliation assessment is prone to observer error (Innes et al. 1993), and QA/QC activities have been routinely implemented to control such an error (e.g. Ferretti and Fischer 2013). It is worth noting, however, that, since our study is aimed at identifying the additional role of N-related variables in a step-wise procedure that compares different models over the same plots, differences in defoliation assessment that could exist among surveyors are likely to have a limited impact on the overall results.

Predictors were chosen on the basis of their availability and include geographical and meteorological variables (in the reference model), reported foliar damage due to reasons other than air pollution (e.g. biotic factors such as pests, or abiotic factors such as storms) (hereafter referred as BADoAP), annual total $\mathrm{N}_{\mathrm{thr}}$ deposition and a set of variables known to be directly or indirectly related to $\mathrm{N}$ deposition, namely foliar $\mathrm{N}$ ratios $(\mathrm{N} / \mathrm{Ca}, \mathrm{N} / \mathrm{P}, \mathrm{N} / \mathrm{K}, \mathrm{N} / \mathrm{Mg}$ ) and soil $\mathrm{pH}$, exchangeable base cations $(\mathrm{BCE})$ and $\mathrm{C} / \mathrm{N}$ ratio in the mineral top soil (Ferretti et al. 2014b; Cools and De Vos 2011; Cools et al. 2014) (Table 1). For both predictors and response variables, assessment and measurement methods were those reported by 


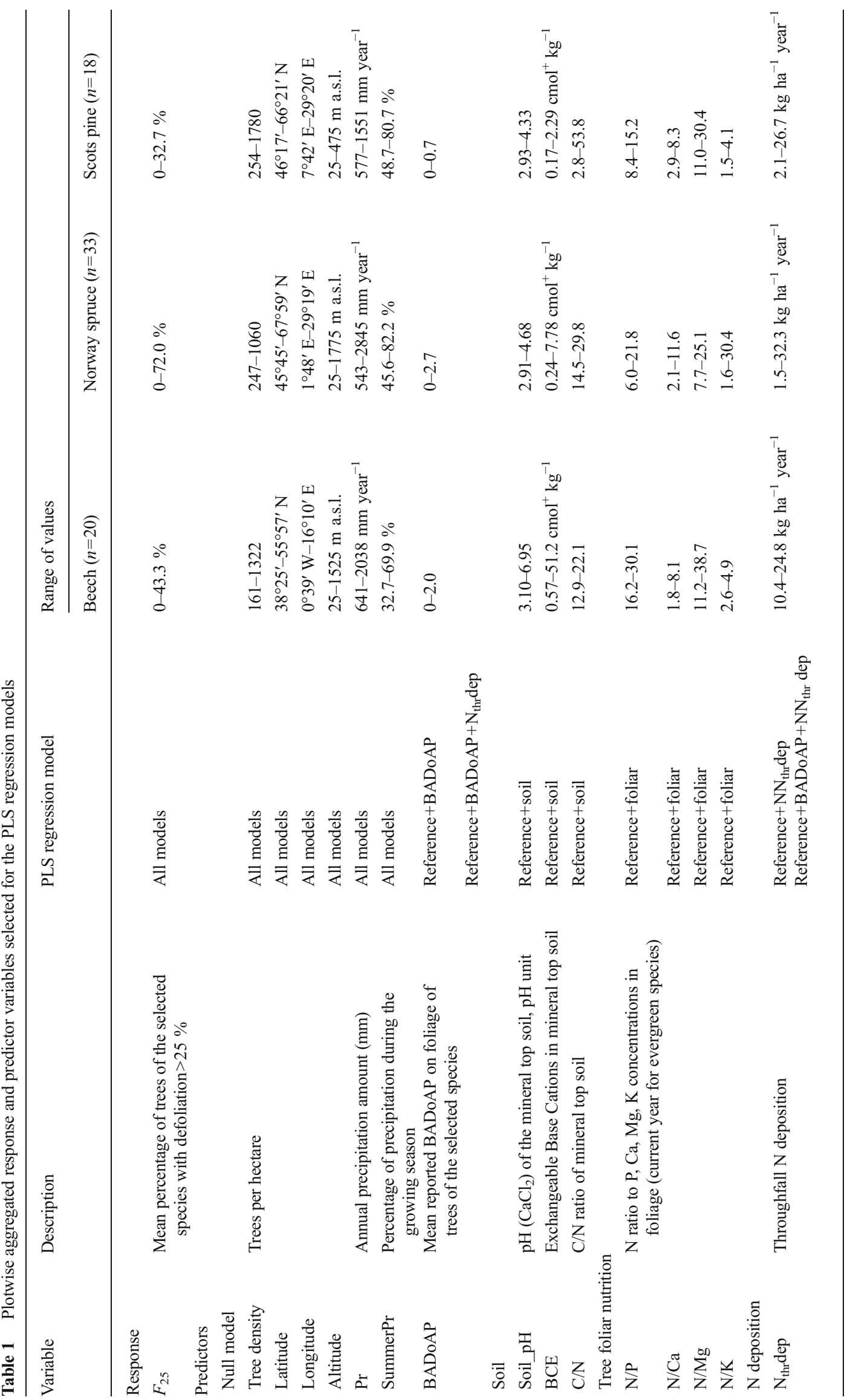


Ferretti and Fischer (2013). BADoAP on foliage were evaluated on an ordinal scale for each tree and averaged for each MTS and plot. Throughfall deposition was sampled by $3-10$ gutters (France and Slovenia) or 10-50 funnels located on a systematic basis (other countries). For most compounds, throughfall deposition is usually larger than open field deposition because the former also includes the dry deposition of compounds collected by the tree canopy. However, in some of the plots used in this study, throughfall deposition of $\mathrm{N}$ compounds (mainly ammonium) was lower than open field deposition because of the active uptake by the foliage (e.g. Ferretti et al. 2014b). Thus, we decided to use $\mathrm{N}_{\text {thr }}$ deposition of total $\mathrm{N}$ as a predictor because it represents the total amount of $\mathrm{N}$ carried to the forest soil through atmospheric deposition and canopy processes. Total $\mathrm{N}_{\text {thr }}$ includes both inorganic and organic N, which has different ecological effects; however, in most of Europe except for northern Fennoscandia, the contribution of organic $\mathrm{N}$ to total $\mathrm{N}_{\mathrm{thr}}$ is relatively low.

Precipitation amounts were measured in a clearing close to the permanent plot. Chemical analyses of foliar tissues were available for 65 plots, while soil analyses were available for 56 plots, and plot average of the topmost mineral layers was considered. Further details on methods for sampling and analysis are reported by Ferretti and Fisher (2013; see also http:// icp-forests.net/page/icp-forests-manual).

\subsection{Statistical methods}

Correlations among variables were explored using Spearman regression. Partial least square (PLS) regression (Wold et al. 2001; Mehmood et al. 2012) was used for statistical modelling of defoliation (Ferretti et al. 2014a). PLS regression generalises and combines features from principal component analysis (PCA) and multiple linear regression (MLR). It is particularly useful when the need is to predict a set of dependent variables $(\boldsymbol{Y})$ from a large set of independent variables $(\boldsymbol{X})$. Among the data mining techniques, PLS regression is considered effective for providing information on the relative importance of predictors (Mehmood et al. 2012), but it does not provide a robust way of testing significance of the coefficients for the predictors. The variable importance in the projections (VIP) scores are used to rank the importance of the predictors, and - since the average of the squared VIP scores equals 1 -variables with scores $>1$ were considered to be the most important (Ferretti et al. 2014a). PLS regression was carried out by the non-linear estimation by iterative partial least squares (NIPALS) algorithm (Geladi and Kowalski 1986) for different set of predictors and separately for each tree species, using the pls package (Mevik and Wehrens 2007). All variables were standardised to zero mean and unit variance, and all analyses were performed in the $\mathrm{R}$ statistical environment (R Core Team 2013).

\section{Results}

\subsection{Descriptive statistics and univariate relationships}

Individual 2007-2009 plot average $F_{25}$ ranged from 0 to $43.3 \%$ in beech, from 0 to $72.0 \%$ for spruce and from 0 to $32.7 \%$ for pine (Table 1). Annual throughfall $\mathrm{N}$ deposition ranged from 1.5 to $32.3 \mathrm{~kg} \mathrm{ha}^{-1}$ and showed significant latitudinal and longitudinal $(p<0.01)$ gradients (Table 2$)$, with the lowest values in northern Finland and maximum values in Germany. Due to the different geographical distribution of tree species, however, the latitudinal gradient was negative for spruce and pine plots ( $\mathrm{N}$ deposition decreases from central Europe to the Nordic countries) and positive for beech ( $\mathrm{N}$ deposition decreases from central Europe to southern Italy and France). This has an effect on the $\mathrm{N}_{\mathrm{thr}}$ deposition gradient experienced by the different species (see Table 1). The more southerly spatial distribution of beech plots, including calcareous areas in Italy and Switzerland (Fig. 1), is reflected in a larger range of $\mathrm{pH}$ and $\mathrm{BCE}$ values for this species (Table 1).

Significant $(p<0.05)$ positive linear relationships were found between $\mathrm{N}_{\text {thr }}$ deposition and the foliar N/P, N/Ca, $\mathrm{N} / \mathrm{Mg}$ and $\mathrm{N} / \mathrm{K}$ ratios, across all data as well as for one or more of the studied tree species (Table 2). A negative relationship was detected between $\mathrm{N}_{\mathrm{thr}}$ deposition and soil $\mathrm{pH}$, measured in the topmost mineral soil, across all data and for pine and spruce plots. A positive relationship between soil $\mathrm{BCE}$ and $\mathrm{N}_{\mathrm{thr}}$ deposition was evident only for pine plots.

Table 2 Spearman rank order correlation coefficient between $\mathrm{N}$ deposition and the other variables considered in the study

\begin{tabular}{lrrrr}
\hline Variable & All plots & Beech & Norway spruce & Scots pine \\
\hline Latitude & -0.34 & 0.58 & -0.38 & -0.71 \\
Longitude & -0.34 & 0.23 & -0.36 & -0.70 \\
Altitude & 0.16 & -0.38 & 0.28 & 0.02 \\
Tree density & -0.25 & -0.05 & -0.28 & -0.16 \\
Pr & 0.33 & -0.23 & 0.53 & 0.18 \\
Summer Pr & -0.18 & 0.00 & -0.28 & 0.14 \\
BADoAP & 0.01 & 0.06 & -0.04 & -0.07 \\
Foliar N/P & 0.43 & -0.14 & 0.48 & 0.74 \\
Foliar N/Ca & 0.18 & 0.55 & 0.62 & -0.14 \\
Foliar N/Mg & 0.44 & 0.21 & 0.40 & 0.59 \\
Foliar N/K & 0.67 & 0.60 & 0.73 & 0.49 \\
Soil pH & -0.46 & -0.40 & -0.51 & -0.76 \\
Soil C/N & -0.12 & 0.34 & 0.18 & -0.33 \\
Soil BCE & 0.27 & -0.24 & 0.07 & 0.63 \\
\hline
\end{tabular}

Significant $(p<0.05)$ values are in italics

$\operatorname{Pr}$ precipitation, BADoAP biotic or abiotic damage other than air pollution 


\subsection{Multivariate analysis}

Factors contributing to explaining the variability of $F_{25}$ were identified using one reference plus five N-related PLS-regression models for each species (see "Material and methods"). As foliar and soil variables were correlated among themselves and with $\mathrm{N}$ deposition, they were added separately to the reference model. When interpreting the results, emphasis should be placed on the effect of the addition of a given group of variables (e.g. foliar $\mathrm{N}$ ratios), while the importance of each variable within the model can be biased by their mutual correlation.

The performance of each model is reported in Table 3. The results showed marked differences among species. The

Table 3 Model performance

\begin{tabular}{|c|c|c|c|c|c|}
\hline Model & $\begin{array}{l}\text { No. of } \\
\text { plots }\end{array}$ & $\begin{array}{l}\text { No. of } \\
\text { LVs }\end{array}$ & $\begin{array}{l}X_{\mathrm{var}} \\
(\%)\end{array}$ & $\begin{array}{l}Y_{\text {var }} \\
(\%)\end{array}$ & RMSEC \\
\hline \multicolumn{6}{|l|}{ Beech } \\
\hline Reference & 20 & 1 & 25.3 & 4.6 & 1.28 \\
\hline Reference $+\mathrm{BADoAP}$ & 20 & 3 & 66.8 & 39.0 & 1.07 \\
\hline Reference $+\mathrm{N}_{\text {thr }}$ dep & 20 & 1 & 14.3 & 19.5 & 1.21 \\
\hline Reference + BADoAP $+\mathrm{N}_{\text {thr }}$ dep & 20 & 2 & 28.4 & 49.3 & 0.96 \\
\hline Reference $^{\mathrm{a}}$ & 18 & 1 & 36.2 & 19.8 & 1.13 \\
\hline Reference + foliar & 18 & 2 & 38.1 & 60.8 & 0.83 \\
\hline Reference $^{\mathrm{a}}$ & 16 & 1 & 39.5 & 6.2 & 1.24 \\
\hline Reference + soil & 16 & 1 & 19.5 & 47.9 & 0.96 \\
\hline \multicolumn{6}{|l|}{ Norway spruce } \\
\hline Reference & 33 & 1 & 46.0 & 8.1 & 1.03 \\
\hline Reference + BADoAP & 33 & 1 & 36.6 & 16.7 & 1.03 \\
\hline Reference $+\mathrm{N}_{\text {thr }}$ dep & 33 & 1 & 42.6 & 12.0 & 1.02 \\
\hline Reference + BADoAP $+\mathrm{N}_{\text {thr }}$ dep & 33 & 1 & 35.6 & 19.5 & 1.00 \\
\hline Reference $^{\mathrm{a}}$ & 29 & 1 & 48.5 & 6.3 & 1.04 \\
\hline Reference + foliar & 29 & 1 & 36.3 & 37.2 & 0.93 \\
\hline Reference $^{\mathrm{a}}$ & 24 & 1 & 53.9 & 8.4 & 1.07 \\
\hline Reference + soil & 24 & 1 & 35.4 & 17.0 & 1.15 \\
\hline \multicolumn{6}{|l|}{ Scots pine } \\
\hline Reference & 18 & 2 & 66.1 & 29.0 & 1.10 \\
\hline Reference + BADoAP & 18 & 2 & 63.4 & 25.2 & 1.07 \\
\hline Reference $+\mathrm{N}_{\text {thr }}$ dep & 18 & 5 & 92.0 & 69.3 & 0.92 \\
\hline Reference $+\mathrm{BADoAP}+\mathrm{N}_{\text {thr }}$ dep & 18 & 5 & 92.0 & 69.6 & 0.96 \\
\hline Reference + foliar & 18 & 1 & 29.4 & 35.4 & 1.03 \\
\hline Reference $^{\mathrm{a}}$ & 16 & 1 & 46.8 & 44.5 & 0.84 \\
\hline Reference + soil & 16 & 4 & 80.5 & 76.9 & 0.74 \\
\hline
\end{tabular}

Number of plots, number of latent variables (LVs), variance explained on the set of predictors $\left(X_{\mathrm{var}}, \%\right)$, variance explained on the response $\left(Y_{\mathrm{var}}\right.$, $\%$ ), root mean square error in cross-validation (RMSEC)

$B A D o A P$ biotic or abiotic damage from known causes other than air pollution, $N_{t h r}$ dep nitrogen throughfall deposition

${ }^{a}$ Models built on a reduced data set to compare with the model presented in the following row of this table reference model was able to explain $4.6 \%$ (beech), $8.1 \%$ (Norway spruce) and $29 \%$ (Scots pine) of the total variation in $F_{25}$ (Table 3 ). The most important predictors in the reference models were latitude (for Norway spruce and Scots pine), longitude (for Norway spruce), tree density (for all species), precipitation (for beech) and summer precipitation (for Scots pine) (Tables 4, 5 and 6). Model performance always improved when a set of N-related predictors was added. This was particularly obvious for beech (up to $41.7 \%$ additional variance explained than in the reference model) and Scots pine (up to $40.6 \%$ ), and less marked for Norway spruce (up to $30.9 \%$ ) (Table 3).

For beech, the contribution of the various sets of N-related predictors in improving the reference model was as follows: foliar $>N_{\text {thr }}$ dep + BADoAP $>$ soil $>$ BADoAP $>N_{\text {thr }}$ dep (Table 3). In particular, $F_{25}$ increases with increasing values of BADoAP, $\mathrm{N}_{\text {thr }}$ dep, the combination of $\mathrm{N}$ deposition and damage, foliar $\mathrm{N}$ ratios $(\mathrm{N} / \mathrm{Ca}, \mathrm{N} / \mathrm{K})$ and soil $\mathrm{C} / \mathrm{N}$, and decreases with increasing values soil $\mathrm{pH}$ and $\mathrm{BCE}$ (Table 4).

For Norway spruce, the contribution of the various sets of predictors in improving the reference model was as follows: foliar $>\mathrm{N}_{\mathrm{thr}}$ dep + BADoAP $>$ BADoAP $\sim$ soil $>\mathrm{N}_{\mathrm{thr}}$ dep (Table 3). In particular, $F_{25}$ increases with $\mathrm{N}$ deposition and damage (single and in combination), foliar N/P, N/Ca, N/Mg and $\mathrm{N} / \mathrm{K}$, and soil BCE, and decreases with soil $\mathrm{C} / \mathrm{N}$ (Table 5).

For Scots pine, the improvement of the reference model was due to soil $>\mathrm{N}_{\text {thr }}$ dep + BADoAP $\sim N_{\text {thr }}$ dep $>$ foliar $>$ BADoAP (Table 3). In particular, $F_{25}$ increases with foliar $\mathrm{N} / \mathrm{P}$ and $\mathrm{N} / \mathrm{Mg}$, and decrease with $\mathrm{N}_{\text {thr }}$ dep and soil $\mathrm{pH}$ and C/N (Table 6).

Table 7 shows the number of models for which each variable obtained a VIP $>1 . \mathrm{N}_{\text {thr }}$ dep and N-related variable obtained VIP $>1$ in almost all models where they were included. In the case of Scots pine, summer precipitation was as important as latitude (also important for Norway spruce) and tree density (all species).

\section{Discussion}

High levels of inorganic $\mathrm{N}$ deposition on forest ecosystems due to anthropogenic activities have been reported for decades in Europe and North America. Most studies have shown how $\mathrm{N}$ deposition affects soil and foliar chemistry, tree growth, carbon sequestration and plant species richness and diversity (e.g. de Vries et al. 2014), but only a few studies have discussed the effects of elevated $\mathrm{N}$ deposition on forest health in terms of defoliation (e.g. Lomsky et al. 2012; Klap et al. 2000 and references therein). Our results suggest that - to different extents - variables related to $\mathrm{N}$ deposition can all contribute to explain the frequency of trees with defoliation $>25 \%$. Positive correlation between $\mathrm{N}$ deposition and $F_{25}$ was 
Table 4 Variable importance in the projections (VIP) score for beech

\begin{tabular}{|c|c|c|c|c|c|c|}
\hline \multirow[t]{2}{*}{ Predictor } & \multicolumn{6}{|l|}{ Models } \\
\hline & Reference & Reference+BADoAP & Reference $+\mathrm{N}_{\text {thr }} \mathrm{dep}$ & Reference $+\mathrm{BADoAP}+\mathrm{N}_{\text {thr }} \mathrm{dep}$ & Reference + foliar & Reference + Soil \\
\hline Latitude & 0.20 & 0.81 & 0.12 & $0.14(-)$ & 1.15 & 0.00 \\
\hline Longitude & $0.28(-)$ & $0.26(-)$ & $0.16(-)$ & $0.67(-)$ & 0.34 & $0.20(-)$ \\
\hline Altitude & $0.34(-)$ & $0.78(-)$ & $0.19(-)$ & $0.20(-)$ & $0.97(-)$ & 0.05 \\
\hline Tree density & $1.53(-)$ & $1.16(-)$ & $0.85(-)$ & $1.23(-)$ & $0.54(-)$ & $0.19(-)$ \\
\hline $\operatorname{Pr}$ & 1.69 & 0.88 & 0.94 & 0.69 & 0.56 & 0.93 \\
\hline Summer Pr & $0.75(-)$ & 0.78 & $0.42(-)$ & 0.58 & $0.95(-)$ & $0.45(-)$ \\
\hline BADoAP & & 1.72 & & 1.55 & & \\
\hline $\mathrm{N}_{\text {thr }}$ dep & & & 2.27 & 1.65 & & \\
\hline Foliar N/P & & & & & 0.27 & \\
\hline Foliar N/Ca & & & & & 1.74 & \\
\hline Foliar N/Mg & & & & & 0.95 & \\
\hline Foliar N/K & & & & & 1.44 & \\
\hline Soil pH $\left(\mathrm{CaCl}_{2}\right)$ & & & & & & $1.69(-)$ \\
\hline Soil C/N & & & & & & 1.85 \\
\hline Soil BCE & & & & & & $1.23(-)$ \\
\hline
\end{tabular}

VIP $>1$ are in italics

(-) negative regression coefficient, $\operatorname{Pr}$ precipitation, BADoAP biotic or abiotic damage for known causes other than air pollution, $N_{t h r} d e p$ nitrogen throughfall deposition

estimated for beech (most of the beech plots have a suboptimal foliar $\mathrm{N}$ status), while a negative one was observed for pine, whose foliar $\mathrm{N}$ status was low for half of the plots located in Nordic countries where also $\mathrm{N}$ deposition is low.
These apparently contradictory effects of $\mathrm{N}$ deposition on defoliation may be explained when considering the different ranges across the investigated $\mathrm{N}$ deposition and saturation gradient covered by the investigated tree species.

Table 5 Variable importance in the projections (VIP) score for Norway spruce

\begin{tabular}{|c|c|c|c|c|c|c|}
\hline \multirow[t]{2}{*}{ Predictor } & \multicolumn{6}{|l|}{ Models } \\
\hline & Reference & Reference+BADoAP & Reference $+\mathrm{N}_{\mathrm{thr}} \mathrm{dep}$ & Reference $+\mathrm{BADoAP}+\mathrm{N}_{\text {thr }}$ dep & Reference + foliar & Reference + Soil \\
\hline Latitude & $1.46(-)$ & $1.21(-)$ & $1.27(-)$ & $1.13(-)$ & $0.72(-)$ & $0.88(-)$ \\
\hline Longitude & $0.91(-)$ & $0.76(-)$ & $0.79(-)$ & $0.71(-)$ & $0.62(-)$ & $0.42(-)$ \\
\hline Altitude & 0.91 & 0.75 & 0.79 & 0.70 & 0.40 & 0.92 \\
\hline Tree density & $1.21(-)$ & $1.01(-)$ & $1.06(-)$ & $0.94(-)$ & $0.54(-)$ & $0.29(-)$ \\
\hline $\operatorname{Pr}$ & 0.78 & 0.65 & 0.68 & 0.60 & 0.39 & 1.71 \\
\hline Summer Pr & $0.38(-)$ & $0.32(-)$ & $0.35(-)$ & $0.30(-)$ & $0.24(-)$ & 0.15 \\
\hline BADoAP & & 1.69 & & 1.57 & & \\
\hline $\mathrm{N}_{\text {thr }}$ dep & & & 1.57 & 1.40 & & \\
\hline Foliar N/P & & & & & 1.09 & \\
\hline Foliar N/Ca & & & & & 1.14 & \\
\hline Foliar N/Mg & & & & & 2.20 & \\
\hline Foliar N/K & & & & & 1.05 & \\
\hline Soil pH $\left(\mathrm{CaCl}_{2}\right)$ & & & & & & $0.92(-)$ \\
\hline Soil C/N & & & & & & $1.03(-)$ \\
\hline Soil BCE & & & & & & 1.51 \\
\hline
\end{tabular}

$\mathrm{VIP}>1$ are in italics

(-) variable with negative coefficient, $\operatorname{Pr}$ precipitation, $B A D o A P$ biotic or abiotic damage for known causes other than air pollution, $N_{t h r}$ dep nitrogen throughfall deposition 
Table 6 Variable importance in the projections (VIP) score for Scots pine

\begin{tabular}{|c|c|c|c|c|c|c|}
\hline \multirow[t]{2}{*}{ Predictor } & \multicolumn{6}{|l|}{ Models } \\
\hline & Reference & Reference+BADoAP & Reference $+\mathrm{N}_{\text {thr }} \mathrm{dep}$ & Reference $+\mathrm{BADoAP}+\mathrm{N}_{\text {thr }} \mathrm{dep}$ & Reference + foliar & Reference + Soil \\
\hline Latitude & $1.20(-)$ & $1.23(-)$ & $1.01(-)$ & $1.02(-)$ & $0.93(-)$ & $0.98(-)$ \\
\hline Longitude & $0.80(-)$ & $0.92(-)$ & $0.91(-)$ & $0.82(-)$ & $0.59(-)$ & $1.22(-)$ \\
\hline Altitude & $0.42(-)$ & $0.42(-)$ & $0.81(-)$ & $0.95(-)$ & $0.33(-)$ & 0.78 \\
\hline Tree density & 1.15 & $1.14(-)$ & 0.94 & 0.92 & 0.89 & 1.08 \\
\hline $\operatorname{Pr}$ & 0.29 & 0.28 & 0.89 & 0.58 & 0.12 & $0.71(-)$ \\
\hline Summer Pr & 1.53 & 1.53 & 1.19 & 1.09 & 1.19 & $0.99(-)$ \\
\hline BADoAP & & 0.88 & & 0.70 & & \\
\hline $\mathrm{N}_{\text {thr }} \mathrm{dep}$ & & & $1.18(-)$ & $1.59(-)$ & & \\
\hline Foliar N/P & & & & & 1.75 & \\
\hline Foliar N/Ca & & & & & $0.65(-)$ & \\
\hline Foliar N/Mg & & & & & 1.46 & \\
\hline Foliar N/K & & & & & 0.94 & \\
\hline Soil pH $\left(\mathrm{CaCl}_{2}\right)$ & & & & & & $1.12(-)$ \\
\hline Soil C/N & & & & & & $1.24(-)$ \\
\hline Soil BCE & & & & & & $0.72(-)$ \\
\hline
\end{tabular}

$\mathrm{VIP}>1$ are in italics

(-) variable with negative coefficient, $\operatorname{Pr}$ precipitation, $B A D o A P$ biotic or abiotic damage for known causes other than air pollution, $N_{t h r} d e p$ nitrogen throughfall deposition

Table 7 Summary of the PLS regression models

\begin{tabular}{|c|c|c|c|c|}
\hline \multirow[t]{2}{*}{ Variables } & \multirow[t]{2}{*}{ No. of models } & \multicolumn{3}{|c|}{ Species } \\
\hline & & Beech & $\begin{array}{l}\text { Norway } \\
\text { spruce }\end{array}$ & Scots pine \\
\hline Latitude & 6 & + & ---- & ---- \\
\hline Longitude & 6 & & & - \\
\hline Altitude & 6 & & & \\
\hline Tree density & 6 & --- & --- & ++- \\
\hline $\operatorname{Pr}$ & 6 & + & + & \\
\hline Summer Pr & 6 & & & ++++ \\
\hline BADoAP & 2 & ++ & ++ & \\
\hline Throughfall $\mathrm{N}$ deposition & 2 & ++ & ++ & -- \\
\hline Foliar N/P & 1 & & + & + \\
\hline Foliar N/Ca & 1 & + & + & \\
\hline Foliar N/Mg & 1 & & + & + \\
\hline Foliar N/K & 1 & + & + & \\
\hline Soil PH $\left(\mathrm{CaCl}_{2}\right)$ & 1 & - & & - \\
\hline Soil C/N & 1 & + & - & - \\
\hline Soil BCE & 1 & - & + & \\
\hline
\end{tabular}

The sign of symbols identify the estimated effect on defoliation (i.e. the sign of the regression coefficient); the number of symbols is equal to the number of models for which the variable obtained a VIP $>1$

$\operatorname{Pr}$ precipitation, $B A D o A P$ biotic or abiotic damage from known causes other than air pollution, no. of models number of PLS-regression models per species including the variable
In fact, the degree of $\mathrm{N}$ saturation (Aber et al. 1998) is an underlying factor/process influencing forest health. For all tree species considered, $F_{25}$ increases with increasing foliar $\mathrm{N}$ ratios, which are good indicators of $\mathrm{N}$-induced nutritional imbalances. In particular, the foliar $\mathrm{N} / \mathrm{Ca}$ and $\mathrm{N} / \mathrm{K}$ ratios were the most influential in the case of beech; foliar N/Mg, N/Ca and N/P for spruce, and foliar N/P and N/Mg for pine, indicating that crown condition in all these tree species is related to imbalance in foliar nutrients (e.g. Veresoglou et al. 2014). $\mathrm{N}$-induced nutrient imbalances can be either caused by direct foliar $\mathrm{N}$ uptake (e.g. Fleischer et al. 2013) or mediated through soil processes (e.g. Moore and Houle 2013). In particular, N deposition effects on soil may include soil acidification, due to nitrification and leaching of nitrate (with possible release of toxic aluminum compounds) and leaching of base cations (for a synthesis, see de Vries et al. 2014). In our data set, soil pH was significantly and negatively correlated with $\mathrm{N}_{\text {thr }}$ deposition $(p<0.01)$, which can probably be explained by similar, though unrelated, geographical gradients. In the Southern Mediterranean part of Europe, soil types tend to be more calcareous and have higher soil $\mathrm{pH}$ values compared to Central or Northern Europe. Simultaneously, N deposition values tend to be lower in Southern and Northern Europe.

The effect of soil $\mathrm{pH}$ on $F_{25}$ was indeed important for beech plots (where the soil $\mathrm{pH}$ ranges between 3.10 and 6.95), but not for Norway spruce and Scots pine (soil pH range, 2.94.7). Similarly, the fact that latitude had a positive effect on beech $F_{25}$ and a negative one on spruce and pine $F_{25}$ is 
probably also due to a "range effect". The effect of latitude in the reference model and of soil $\mathrm{pH}$ in the model including soil variables probably accounts for part of the effect of the deposition and $\mathrm{N}$ saturation gradient in Europe.

The impact of leaching of base cations on tree nutrition, coupled to an increased availability of $\mathrm{N}$, leads to positive relationships between $\mathrm{N}$ deposition and foliar $\mathrm{N}$ ratios, as shown in many observational and fertilisation studies (e.g. de Vries et al. 2014). In our data, almost all foliar ratios increase with increasing $\mathrm{N}$ deposition. In particular, the significant relationship between $\mathrm{N}_{\text {thr }}$ deposition and foliar $\mathrm{N} / \mathrm{K}$ for all tree species supports the hypothesis of $\mathrm{K}$ leached from leaf tissue in exchange with ammonium ions (Moreno et al. 2001) as K does not easily leach from soil. More generally, N deposition may alter both terms of the foliar $\mathrm{N}$ ratios. On the one hand, $\mathrm{N}$ deposition improves $\mathrm{N}$ nutrition, and on the other hand, it can contribute to deteriorated nutrition of other nutrients by acting as a fertiliser promoting tree growth and therefore increasing nutrient demand by trees (Lukac et al. 2010), by reducing nutrient uptake capacity of trees due to reduced carbon allocation to roots and detrimental effects on mycorrhiza (Kjøller et al. 2012) and by reducing nutrient availability in the soil due to acidification.

In summary, $\mathrm{N}$ deposition and $\mathrm{N}$-deposition-related variables at soil and foliar level improved substantially (3.9$41.7 \%$, according to the species and the predictor) explanatory models of the frequency of defoliated trees in beech, Norway spruce and Scots pine across Europe.

\begin{abstract}
Acknowledgements We gratefully acknowledge the Program Coordination Center of ICP Forests and the field crews that performed the field work. We acknowledge the National Focal Centers of ICP Forests in Denmark (Forest \& Landscape), Estonia (Estonian Environment Agency), Finland (METLA), France (RENECOFOR), Germany (Bundesministerium für Ernährung, Landwirtschaft und Verbraucherschutz), Italy (National Forestry Service, CFS), Norway (Norwegian Forest and Landscape Institute, NFLI), Slovenia (Slovenian Forestry Institute) and Switzerland (WSL). Many colleagues contributed to analyses, data collection and management. In particular, we thank Vladislaw Apuhtin, Ulle Nappa (Estonian Environment Agency), Matthias Dobbertin, Maria Schmitt, Lorenz Walthert (WSL, Switzerland), Richard Fischer, Uwe Fischer, Martin Lorenz, Volker Mues, Walter Seidling (TI, Germany), Oliver Granke (formerly at TI, Germany), Reinhard Kallweit (LFE, Germany), Alexander Menzer (Sachsenforst, Germany), Morten Ingerslev, Lars Vesterdal (Forest \& Landscape, Denmark), Kjell Andreassen (NFLI, Norway), Hans-Werner Schroeck (FAWF, Germany), Georg Kindermann, Markus Neumann (BFW, Austria), Antti-Jussi Lindroos, Nöjd Pekka (METLA, Finland), Henning Meesenburg (NW FVA, Germany), Manuel Nicolas (ONF, France), Peter Roskams (INBO, Belgium), Claus Schimming (University of Kiel), ElenaVanguelova (Forest Research, UK) and Daniel Žlindra (SFI, Slovenia).
\end{abstract}

Funding The long-term collection of forest monitoring data was partially funded by the European Union under the Regulation (EC) No. 2152/2003 concerning monitoring of forests and environmental interactions in the Community (Forest Focus) and the project LIFE $07 \mathrm{ENV} / \mathrm{D} /$ 000218 "Further Development and Implementation of an EU-level Forest Monitoring System (FutMon)". Funding was also provided by national research institutions and funding agencies in participating countries.

\section{References}

Aber J, McDowell W, Nadelhoffer K, Magill A, Bernston G, Kamakea M, McNulty S, Currie W, Rustad L, Fernandez I (1998) Nitrogen saturation in temperate forest ecosystems. Bioscience 48:921-934

Braun S, Schindler C, Volz R, Fluckiger W (2003) Forest damages by the storm 'Lothar' in permanent observation plots in Switzerland: the significance of soil acidification and nitrogen deposition. Water Air Soil Pollut 142:327-340

Cools N, De Vos B (2011) Availability and evaluation of European forest soil monitoring data in the study on the effects of air pollution on forests. iForest 4:205-211. doi:10.3832/ifor0588004

Cools N, Vesterdal L, De Vos B, Vanguelova E, Hansen K (2014) Tree species is the major factor explaining $\mathrm{C}: \mathrm{N}$ ratios in European forest soils. Forest Ecol Manag 311:3-16

R Core Team (2013) R: A language and environment for statistical computing. R Foundation for Statistical Computing, Vienna, Austria. URL http://www.R-project.org/.

de Vries W, Dobbertin MH, Solberg S, van Dobben HF, Schaub M (2014) Impacts of acid deposition, ozone exposure and weather conditions on forest ecosystems in Europe: an overview. Plant Soil 380:1-45. doi:10.1007/s11104-014-2056-2

Dobbertin M (2005) Tree growth as indicator of tree vitality and of reaction to environmental stress: a review. Eur J Forest Res 124: 319-333. doi:10.1007/s10342-005-0085-3

Erisman JW, Galloway J, Seitzinger S, Bleeker A, Butterbach-Bahl K (2011) Reactive nitrogen in the environment and its effect on climate change. Curr Opin Env Sust 3:281-290. doi:10.1016/j.cosust.2011. 08.012

Ferretti M, Fischer R (eds) (2013) Forest monitoring - methods for terrestrial investigations in Europe with an overview of North America and Asia, Developments in Environmental Science, vol 12. Elsevier, Oxford, $507 \mathrm{p}$

Ferretti M, Nicolas M, Bacaro G, Brunialti G, Calderisi M, Croisé L, Frati L, Lanier M, Maccherini S, Santi E, Ulrich E (2014a) Plot-scale modelling to detect size, extent, and correlates of changes in tree defoliation in French high forests. Forest Ecol Manag 311:56-69. doi:10.1016/j.foreco.2013.05.009

Ferretti M, Marchetto A, Arisci S, Bussotti F, Calderisi M, Carnicelli S, Cecchini G, Fabbio G, Bertini G, Matteucci G, De Cinti B, Salvati L, Pompei E (2014b) On the tracks of nitrogen deposition effects on temperate forests at their southern European range - an observational study from Italy. Global Change Biol 20:3423-3438. doi:10.1111/ gcb. 12552

Fleischer K, Rebel KT, van der Molen MK, Erisman JW, Wassen MJ, van Loon EE, Montagnani L, Gough CM, Herbst M, Janssens IA, Gianelle D, Dolman AJ (2013) The contribution of nitrogen deposition to the photosynthetic capacity of forests. Glob Biogeochem Cy 27:187-199. doi:10.1002/gbc.20026

Forest Europe (2011) State of Europe's Forests 2011. Status and Trends in Sustainable Forest Management in Europe

Geladi P, Kowalski B (1986) Partial least squares regression: a tutorial. Anal Chim Acta 185:1-17

Innes JL, Landmann G, Mettendorf B (1993) Consistency of observation of forest tree defoliation in three European countries. Environ Monit Assess 25:29-40

Kjøller R, Nilsson LO, Hansen K, Schmidt K, Vesterdal L, Gundersen P (2012) Dramatic changes in ectomycorrhizal community composition, root tip abundance and mycelial production along a stand-scale nitrogen deposition gradient. New Phytol 194:278-286. doi:10. 1111/j.1469-8137.2011.04041.x

Klap J, Oude Voshaar J, De Vries W, Erisman J (2000) Effects of environmental stress on forest crown condition in Europe. 
Part IV. Statistical analysis of relationships. Wat Air Soil Pollut 119:387-420

Lamarque JF, Kiehl JT, Brasseur GP, Butler T, Cameron-Smith P, Collins WD, Collins WJ, Granier C, Hauglustaine D, Hess PG, Holland EA, Horowitz L, Lawrence MG, McKenna D, Merilees P, Prather MJ, Rasch PJ, Rotman D, Shindell D, Thornton P (2005) Assessing future nitrogen deposition and carbon cycle feedback using a multimodel approach: analysis of nitrogen deposition. J Geophys Res 110:1-21. doi:10.1029/2005JD005825

Lomsky B, Sramek V, Novotny R (2012) Changes in the air pollution load in the Jizera Mts.: effects on the health status and mineral nutrition of the young Norway spruce stands. Eur J Forest Res 131:757-771. doi:10.1007/s10342-011-0549-6

Lukac M, Calfapietra C, Lagomarsino A et al (2010) Global climate change and tree nutrition: effects of elevated $\mathrm{CO}_{2}$ and temperature. Tree Physiol 30:1209-1220. doi:10.1093/treephys/tpq040

Mehmood T, Liland KH, Snipen L, Saebo S (2012) A review of variable selection methods in partial least squares regression. Chemometr Intell Lab 118:62-69. doi:10.1016/j.chemolab.2012.07.010
Mevik BH, Wehrens R (2007) The pls package: principal component and partial least squares regression in R. J Stat Softw 18:1-24

Moore JD, Houle D (2013) Soil and sugar maple response to 8 years of $\mathrm{NH}_{4} \mathrm{NO}_{3}$ additions in a base-poor northern hardwood forest. Forest Ecol Manag 310:167-172. doi:10.1016/j.foreco.2013.08.020

Moreno G, Gallardo JF, Bussotti F (2001) Canopy modification of atmospheric deposition in oligotrophic Quercus pyrenaica forests of an unpolluted region (Central-Western Spain). Forest Ecol Mana 149:47-60

Roelofs JGM, Kempers AJ, Houdijk ALFM, Jansen J (1985) The effect of air-borne ammonium sulphate on Pinus nigra var. maritima in the Netherlands. Plant Soil 84:45

Veresoglou SD, Peñuelas J, Fischer R, Rautio P, Sardans J, Merila P, Tabakovic-Tosic M, Rillig MC (2014) Exploring continental-scale stand health $-\mathrm{N}: \mathrm{P}$ ratio relationships for European forests. New Phytol 202:422-430. doi:10.1111/nph.12665

Wold S, Sjöström M, Eriksson L (2001) PLS-regression: a basic tool of chemometrics. Chemometr Intell Lab 58:109-130. doi:10.1016/ S0169-7439(01)00155-1 